\title{
Front Matter: Volume 8835
}

, "Front Matter: Volume 8835," Proc. SPIE 8835, LED-based Illumination Systems, 883501 (30 September 2013); doi: 10.1117/12.2033978

SPIE Event: SPIE Optical Engineering + Applications, 2013, San Diego, California, SPIE. United States 


\title{
PROCEEDINGS OF SPIE
}

\section{LED-based Illumination Systems}

\author{
Jianzhong Jiao \\ Editor
}

26 August 2013

San Diego, California, United States

Sponsored and Published by

SPIE

Volume 8835 
The papers included in this volume were part of the technical conference cited on the cover and title page. Papers were selected and subject to review by the editors and conference program committee. Some conference presentations may not be available for publication. The papers published in these proceedings reflect the work and thoughts of the authors and are published herein as submitted. The publisher is not responsible for the validity of the information or for any outcomes resulting from reliance thereon.

Please use the following format to cite material from this book:

Author(s), "Title of Paper," in LED-based Illumination Systems, edited by Jianzhong Jiao, Proceedings of SPIE Vol. 8835 (SPIE, Bellingham, WA, 2013) Article CID Number.

ISSN: 0277-786X

ISBN: 9780819496850

Published by

SPIE

P.O. Box 10, Bellingham, Washington 98227-0010 USA

Telephone +1 3606763290 (Pacific Time) · Fax +1 3606471445

SPIE.org

Copyright @ 2013 , Society of Photo-Optical Instrumentation Engineers.

Copying of material in this book for internal or personal use, or for the internal or personal use of specific clients, beyond the fair use provisions granted by the U.S. Copyright Law is authorized by SPIE subject to payment of copying fees. The Transactional Reporting Service base fee for this volume is $\$ 18.00$ per article (or portion thereof), which should be paid directly to the Copyright Clearance Center (CCC), 222 Rosewood Drive, Danvers, MA 01923. Payment may also be made electronically through CCC Online at copyright.com. Other copying for republication, resale, advertising or promotion, or any form of systematic or multiple reproduction of any material in this book is prohibited except with permission in writing from the publisher. The CCC fee code is $0277-786 \mathrm{X} / 13 / \$ 18.00$.

Printed in the United States of America.

Publication of record for individual papers is online in the SPIE Digital Library.

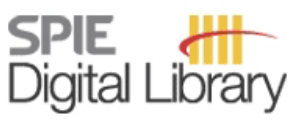

SPIEDigitalLibrary.org

Paper Numbering: Proceedings of SPIE follow an e-First publication model, with papers published first online and then in print and on CD-ROM. Papers are published as they are submitted and meet publication criteria. A unique, consistent, permanent citation identifier (CID) number is assigned to each article at the time of the first publication. Utilization of CIDs allows articles to be fully citable as soon as they are published online, and connects the same identifier to all online, print, and electronic versions of the publication. SPIE uses a six-digit CID article numbering system in which:

- The first four digits correspond to the SPIE volume number.

- The last two digits indicate publication order within the volume using a Base 36 numbering

system employing both numerals and letters. These two-number sets start with 00, 01, 02, 03, 04,

05, 06, 07, 08, 09, 0A, OB ... 0Z, followed by 10-1Z, 20-2Z, etc.

The CID Number appears on each page of the manuscript. The complete citation is used on the first page, and an abbreviated version on subsequent pages. Numbers in the index correspond to the last two digits of the six-digit CID Number. 


\section{Contents}

vii Conference Committee
ix Introduction

\section{SESSION 1 PHOTON RADIANCE AND THERMAL INDUCED DEGRADATIONS}

883502 Accelerated optical polymer aging studies for LED luminaire applications [8835-1]

E. Estupiñán, P. Wendling, M. Kostrun, R. Garner, OSRAM SYLVANIA Inc. (United States)

883504 Thermal management of the remote phosphor layer in LED systems [8835-3]

I. U. Perera, N. Narendran, Rensselaer Polytechnic Institute (United States)

883506 Accurate measurement of LED lens surface temperature [8835-5]

I. U. Perera, N. Narendran, Y. Liu, Rensselaer Polytechnic Institute (United States)

\section{SESSION 2 COLOR: ACHIEVABILITY AND PERCEPTION}

883507 Context-aware tunable office lighting application and user response [8835-6]

N. H. Chen, OSRAM SYLVANIA Inc. (United States); J. Nawyn, Massachusetts Institute of Technology Media Lab. (United States); M. Thompson, J. Gibbs, OSRAM SYLVANIA Inc. (United States); K. Larson, Massachusetts Institute of Technology Media Lab. (United States)

883508 Color preferences revealed by statistical color rendition metric [8835-7]

A. Liu, Rensselaer Polytechnic Institute (United States); A. Tuzikas, A. Žukauskas,

R. Vaicekauskas, P. Vitta, Vilnius Univ. (Lithuania); M. Shur, Rensselaer Polytechnic Institute (United States)

\section{SESSION 3 OPTICAL AND SYSTEM DESIGN CHALLENGES IN LED-BASED ILLUMINATION SYSTEM I}

8835 OD Data format standard for sharing light source measurements [8835-12]

G. G. Gregory, Synopsys, Inc. (United States); I. Ashdown, byHeart Consultants Ltd. (Canada); W. Brandenburg, Brandenburg GmbH (Germany); D. Chabaud, OPTIS (France); O. Dross, Philips Research (Netherlands); S. Gangadhara, Radiant Zemax, LLC (United States); K. Garcia, Breault Research Organization, Inc. (United States); M. Gauvin, Lambda Research (United States); D. Hansen, opsira GmbH (Germany); K. Haraguchi, Nichia America Corp. (United States); G. Hasna, OPTIS (France); J. Jiao, OSRAM Opto Semiconductors Inc. (United States); R. Kelley, LTI Optics, LLC (United States); J. Koshel, Photon Engineering LLC (United States); J. Muschaweck, OSRAM GmbH (Germany)

8835 OE LED light recycling using double prisms [8835-13]

G. Ouyang, K. Li, Wavien, Inc. (United States)

8835 OF System design of a LED based gobo projector [8835-14]

H. Rehn, OSRAM AG (Germany) 
8835 OG Design of LED edge-lit light bar for automotive taillight applications [8835-15]

J.-C. Yu, J.-H. Chen, S.-C. Liu, National Kaohsiung First Univ. of Science and Technology (Taiwan)

$8835 \mathrm{OH} \quad$ Effect of a light guide plate with lenticular-arrayed surface on optical output for backlight and illumination application [8835-16]

T.-C. Teng, L.-W. Tseng, National Taiwan Normal Univ. (Taiwan)

8835 Ol Diffraction gratings for lighting applications [8835-17]

H. J. Cornelissen, D. K. G. de Boer, T. Tukker, Philips Research (Netherlands)

$88350 \mathrm{~J} T$ Thermal and optical aspects of glob-top design for phosphor converted white LED light sources [8835-18]

C. Sommer, JOANNEUM RESEARCH Forschungsgesellschaft mbH (Austria); P. Fulmek, J. Nicolics, Technische Univ. Wien (Austria); S. Schweitzer, W. Nemitz, P. Hartmann, JOANNEUM RESEARCH Forschungsgesellschaft mbH (Austria); P. Pachler, H. Hoschopf, F. Schrank, Tridonic Jennersdorf GmbH (Austria); G. Langer, Austria Technologie \& Systemtechnik AG (Austria); F. P. Wenzl, JOANNEUM RESEARCH Forschungsgesellschaft $\mathrm{mbH}$ (Austria)

8835 OK Object-oriented emission-adaptive phosphor layer for pc-white LED [8835-19]

K.-C. Lee, D. Kim, S.-R. Gang, J. H. Baek, Korea Photonics Technology Institute (Korea, Republic of)

\section{SESSION 5 MAINTENANCE AND RELIABILITY}

$8835 \mathrm{OL}$ Insights into accelerated aging of SSL luminaires [8835-20]

J. L. Davis, M. Lamvik, J. Bittle, S. Shepherd, R. Yaga, N. Baldasaro, E. Solano, G. Bobashev, RTI International (United States)

8835 OM Prediction of L70 lumen maintenance and chromaticity for LEDs using extended Kalman filter models [8835-21]

P. Lall, J. Wei, Auburn Univ. (United States); L. Davis, RTI International (United States)

$8835 \mathrm{ON}$ The impact of the color conversion element configuration on its thermal response in phosphor converted LEDs [8835-22]

F. P. Wenzl, JOANNEUM RESEARCH Forschungsgesellschaft mbH (Austria); P. Fulmek, Technische Univ. Wien (Austria); C. Sommer, P. Hartmann, JOANNEUM RESEARCH Forschungsgesellschaft mbH (Austria); P. Pachler, H. Hoschopf, F. Schrank, Tridonic Jennersdorf GmbH (Austria); G. Langer, Austria Technologie \& Systemtechnik AG (Austria); J. Nicolics, Technische Univ. Wien (Austria)

$883500 \quad$ A driving scheme to reduce AC LED flicker [8835-23]

J. Tan, N. Narendran, Rensselaer Polytechnic Institute (United States) 
8835 OP Luminescence properties of rare earth ions doped glasses excited by broadband lights [8835-24]

L. Ren, X. Lei, W. Chen, X. Du, L. Jin, Chongqing Univ. (China)

8835 OR Monte Carlo simulation of radiation pattern for rare earth ions doped luminescent glasses under violet LED excitation [8835-26]

X. Lei, Y. Feng, W. Chen, P. Zhang, L. Ren, X. Du, Chongqing Univ. (China)

POSTER SESSION

$88350 \mathrm{X} \quad$ Adjustable and automated system to obtain 2-D photometric patterns [8835-32] M. Tecpoyotl-Torres, J. G. Vera-Dimas, S. E. Martínez-Fabián, J. L. Mendoza-Zúñiga, J. Escobedo-Alatorre, Univ. Autónoma del Estado de Morelos (Mexico);

O. G. Ibarra-Manzano, Univ. de Guanajuato (Mexico); V. V. Grimalsky, Univ. Autónoma del Estado de Morelos (Mexico)

8835 OY Evaluation of optical and chromatic properties under electrical and thermal coupling in solid state lighting systems [8835-33]

H.-K. Fu, Y.-P. Peng, C.-P. Wang, H.-C. Chiang, T.-T. Chen, C.-L. Chen, P.-T. Chou, Industrial Technology Research Institute (Taiwan)

$88350 Z$ The low-frequency noise spectrum analysis of the reliability of the InGaN LED [8835-34] T.-T. Chen, C.-F. Dai, C.-W. Chu, H.-K. Fu, C.-P. Wang, P.-T. Chou, Industrial Technology Research Institute (Taiwan)

883510 Long-term lumen depreciation behavior and failure modes of multi-die array LEDs [8835-35]

A. Jayawardena, D. Marcus, X. Prugue, N. Narendran, Rensselaer Polytechnic Institute (United States)

Author Index 


\title{
Conference Committee
}

\author{
Program Track Chair
}

Ian T. Ferguson, The University of North Carolina at Charlotte (United States)

Conference Chair

Jianzhong Jiao, OSRAM Opto Semiconductors Inc. (United States)

\section{Conference Program Committee}

Srinath K. Aanegola, GE Global Research (India)

Ian E. Ashdown, byHeart Consultants Ltd. (Canada)

Lianghui Chen, Institute of Semiconductors (China)

Wood-Hi Cheng, National Sun Yat-Sen University (Taiwan)

John W. Curran, LED Transformations, LLC (United States)

Nikolaus Dietz, Georgia State University (United States)

Ian T. Ferguson, The University of North Carolina at Charlotte (United States)

Samuel Graham, Georgia Institute of Technology (United States)

Christoph Hoelen, Philips Lighting B.V. (Netherlands)

Jian-Jang Huang, National Taiwan University (Taiwan)

Matthew H. Kane, Texas A\&M University at Galveston (United States)

Asif M. Khan, University of South Carolina (United States)

Michael R. Krames, Soraa, Inc. (United States)

Yung Sheng Liu, National Tsing Hua University (Taiwan)

Nadarajah Narendran, Rensselaer Polytechnic Institute (United States)

Seong-Ju Park, Gwangju Institute of Science and Technology (Korea,

Republic of)

Robert V. Steele, Strategies Unlimited (United States)

Christian Wetzel, Rensselaer Polytechnic Institute (United States)

Chih-Chung Yang, National Taiwan University (Taiwan)

Yiting Zhu, Rensselaer Polytechnic Institute (United States)

Session Chairs

1 Photon Radiance and Thermal Induced Degradations

Jianzhong Jiao, OSRAM Opto Semiconductors Inc. (United States)

2 Color: Achievability and Perception

Nadarajah Narendran, Rensselaer Polytechnic Institute (United States)

3 Optical and System Design Challenges in LED-based Illumination System I

Hugo J. Cornelissen, Philips Research Nederland B.V. (Netherlands) 
4 Optical and System Design Challenges in LED-based Illumination System II Matthew H. Kane, Texas A\&M University at Galveston (United States)

5 Maintenance and Reliability

Wood-Hi Cheng, National Sun Yat-Sen University (Taiwan)

6 Advanced LED Technologies

Jianzhong Jiao, OSRAM Opto Semiconductors Inc. (United States) 


\section{Introduction}

These proceedings are focused on the LED-based illuminating systems.

LED die and package technologies have been quickly evolving and improving in the past several years. Sufficient luminous flux, high efficacy, and long durability of the LEDs led to rapid implementation of LED-based illuminating systems or solidstate lighting (SSL). Not only does the SSL bring in the energy saving benefit, the potentials of lighting performance quality has also been demonstrated.

The technical challenges in the implementation of SSL may be presented in the areas of lighting system configuration, optical design, thermal management, electronics and controls, reliability, and testing methods. Studies and research have been carried in both industry and academia. These research results indicate a trend for wider applications of LED-based illuminating systems.

In addition, standardization of SSL has also made progress. Both LED package level and LED illuminating system level standards have been established for chromaticity, lumen maintenance, and safety.

These proceedings will demonstrate accomplishments and status of SSL technologies.

Jianzhong Jiao 